\title{
SISTEM INFORMASI POSYANDU PENDATAAN \\ KESEHATAN BALITA, IBU HAMIL, DAN LANSIA PADA POSYANDU SUKA MULYA DESA KEPONGPONGAN
}

\author{
Sri Risma Wati ${ }^{1}$, Lena Magdalena ${ }^{2}$, Muhammad Hatta ${ }^{3}$, Reza Ilyasa ${ }^{4}$ \\ Universitas Catur Insan Cendekia \\ J1. Kesambi No. 202, Cirebon \\ e-mail: srirismaw@gmail.com ${ }^{1}$, lena.magdalena@cic.ac.id ${ }^{2}$, \\ muhammad.hatta@cic.ac.id ${ }^{3}$, reza.ilyasa@cic.ac.id ${ }^{4}$
}

\begin{abstract}
ABSTRAK
Posyandu adalah wadah pemeliharaan kesehatan yang dilakukan dari, oleh dan untuk masyarakat yang dibimbing petugas terkait. Sistem pendatatan di posyandu Suka Mulya ini masih menggunakan sistem yang manual dan sederhana masih menggunakan buku bersifat konvensional. Sehingga menimbulkan kesalahan pencatatan infomasi mengenai data kesehatan dikarenakan form laporan sangat kecil membuat hasil laporannya tidak jelas dan susah untuk dibaca.

Dengan adanya sistem yang masih manual dokumen-dokumen penting mudah hilang ataupun rusak, yang berdampak pada kerugian petugas posyandu dalam menjalankan kegiatan Maka dari itu dibutuhkan pemanfaatan sistem informasi untuk menyelesaikan permasalahan yang terjadi dengan membuat sebuah sistem yang dapat membantu untuk melakukan penyimpanan data kesehatan Balita, Ibu Hamil dan lansia, maka dari itu dibuatlah sipplus yang merupakan sistem informasi untuk menyelesaikan permasalahan tersebut. Sipplus dapat digunakan oleh Petugas Posyandu untuk mengelola data kesehatan bayi, ibu hamil, lansia dan Kepala Puskesmas menerima informasi Kesehatan melalui Sipplus tentang Informasi kesehatan bayi, ibu hamil, dan lansia, Perancangan Sipplus ini menggunakan bahasa PHP Hypertext Prepocessor dan perangkat lunak $M y S q l$ sebagai media penyimpanan, untuk rancangan sistem terkomputerisasi disusun dalam Use case, diagram Activity, Sequence diagram, Class diagram.

Hasil dari penelitian ini adalah Sistem Informasi yang bernama Sipplus yang terdapat fungsi untuk mengelola pendataan kesehatan di dalam kegiatan posyandu Dari hasil implementasi tersebut mengasilkan sebuah output yang berupa laporan Format 1 - Format 6 berdasarkan format laporan dinas kesehatan, dan terdapat tambahan daftar hadir bayi, daftar hadir ibu hamil, daftar hadir lansia, daftar hadir petugas posyandu dan laporan pemeriksaan kesehatan lansia untuk informasi kegiatan pemeriksaan kesehatan di posyandu, Berdasarkan output tersebut dapat disimpulkan bahwa Sistem Informasi yang telah dibuat dapat diterapkan pada Posyandu.
\end{abstract}

Kata kunci : Sipplus, Posyandu, ,Sistem, Informasi, Kesehatan

\section{ABSTRACT}

Posyandu is a place for health maintenance carried out from, by and for the community, guided by relevant officers. The recording system at the Posyandu Suka Mulya still uses a manual and simple system that still uses conventional books. Giving rise to errors in recording information about health data because the report form is very small making the results of the report unclear and difficult to read.

With the system that is still manual important documents are easily lost or damaged, which impacts on the loss of posyandu officers in carrying out activities. Therefore, it is necessary to use information systems to solve problems that occur by creating a system that can help to store toddlers health data, Pregnant women and the elderly, therefore made sipplus which is an information system to solve these problems. Sipplus can be used by Posyandu Officers to manage health data for infants, pregnant women, the elderly and the Head of the Community Health Center to receive health information through Sipplus about health information for infants, pregnant women, and the elderly, this Sipplus Design uses PHP Hypertext 
Prepocessor and MySql software as storage media, for computerized system designs arranged in Use cases, Activity diagrams, Sequence diagrams, Class diagrams.

The results of this study are the Information System named Sipplus which has a function to manage health data collection in posyandu activities. From the results of the implementation it produces an output in the form of report Format 1-6 reports are based on the health service report format, and there are additional baby attendance lists, pregnant women attendance lists, elderly attendance lists, attendance lists of posyandu officers and elderly health examination reports for information on health inspection activities at posyandu, Based on these outputs it can be concluded that the Information System that have been made can be applied to Posyandu.

\section{Keywords: Sipplus, Posyandu, System, Information, Health}

\section{PENDAHULUAN}

Posyandu adalah wadah pemeliharaan kesehatan yang dilakukan dari, oleh dan untuk masyarakat yang dibimbing petugas terkait. (Departemen Kesehatan RI, 2006). Posyandu merupakan sarana penting di masyarakat yang mendukung dalam mewujudkan penurunan angka kematian anak dan meningkatkan kesejahteraan ibu. Posyandu dicanangkan tahun 1986, jumlah posyandu di Indonesia tercatat 25.000 posyandu dan tahun 2011 terdapat 268.439 posyandu dengan jumlah kader 131.383 orang (Nurayu, A. W, 2013)

Saat ini sistem informasi dioperasikan oleh hampir seluruh sumber daya manusia suatu organisasi sehingga tidak dapat dipisahkan dengan operasi dan kehidupan organisasi. Dengan Penerapan Sistem Informasi Pendataan sangat membantu khususnya dalam Posyandu, dengan adanya Sistem Informasi di Posyandu ini maka pengelolaan data-data untuk laporan Balita, Ibu Hamil dan Lansia akan berjalan efektif dan efisien mengingat pendataan yang masih dalam bentuk kertas dan tabel, sehingga sering terjadi kesalahan pencatatan, tidak jelas dalam penulisan, memakan waktu dalam pencarian nama balita/ibu hamil/lansia.

Dari penelitian yang dilakukan oleh Bella Hardiyana, S.Kom, M.Kom dan Irfan Suendi, Amd.Kom tahun 2013 dalam judul Sistem informasi Pendataan Balita di Posyandu Dahlia RW/RT 12/05 Kec. Baleendah, Kel. Baleendah, Kab. Bandung dalam penelitian tersebut terdapat Sistem Informasi Pendataan Balita yang dapat memberikan informasi dan mempermudah dalam proses pengolahan data balita dan pembuatan laporan. Maka dari itu dengan dibuatnya sistem informasi akan sangat membantu dalam kegiatan di Posyandu Suka Mulya.

\section{KAJIAN PUSTAKA}

\subsection{Sistem Informasi}

Menurut Krismiaji dalam bukunya yang berjudul Sistem Informasi Akuntansi. Sistem informasi adalah cara-cara yang diorganisasi untuk mengumpulkan, memasukkan dan mengolah serta menyimpan data, dan cara-cara yang diorganisasi untuk menyimpan, mengelola, mengendalikan, dan melaporkan informasi sedemikian rupa sehingga sebuah organisasi dapat mencapai tujuan yang telah ditetapkan. [1]

\subsection{Posyandu}

Posyandu merupakan salah satu bentuk Upaya Kesehatan Bersumber Daya Masyarakat (UKBM) yang dikelola dan diselenggarakan dari, oleh, untuk dan bersama masyarakat dalam penyelenggaraan pembangunan kesehatan, guna memberdayakan masyarakat dan memberikan kemudahan kepada masyarakat dalam memperoleh pelayanan kesehatan dasar untuk mempercepat penurunan angka kematian ibu dan bayi. [2]

\subsection{Konsep Dasar Kesehatan Bayi/Balita}

Balita adalah anak usia 1-3 tahun (batita) dan anak prasekolah 3-5 tahun. Pada usia ini anak masih tergantung pada orang tuanya dalam melakukan hal-hal penting, misalnya seperti mandi, makan, ganti pakaian dan buang air. Perkembangan bicara dan berjalan sudah bertambah baik tapi kemampuan lainnya masih terbatas [3]

Untuk menentukan status Gizi pada bayi dan balita di posyandu suka mulya ditentukan berdasarkan umur dan standar Antropometri, Antropometri berasal dari kaya antropos yang artinya tubuh dan metros

Sistem Informasi Posyandu Pendataan Kesehatan Balita, Ibu Hamil, dan Lansia Pada Posyandu Suka Mulya Desa Kepongpongan - (Sri Risma Wati, Lena Magdalena, Muhammad Hatta, Reza Ilyasa) 
yang berarti ukuran. Jadi antropometri artinya ukuran tubuh. Antropometri gizi berhubungan dengan berbagai macam pengukuran dimensi tubuh dan komposisi tubuh dari berbagai tingkat umur dan tingkat gizi

\subsection{Konsep Dasar Kesehatan Ibu Hamil}

Ibu hamil adalah seorang wanita yang mengandung dimulai dari konsepsi sampai lahirnya janin Kehamilan adalah masa di mana seorang wanita membawa embrio atau fetus di dalam tubuhnya. Kehamilan manusia terjadi selama 40 minggu antara waktu menstruasi terakhir dan kelahiran (38 minggu dari pembuahan).

Penilaian Secara Antropometri, Antropometri adalah ilmu yang mempelajari berbagai ukuran tubuh manusia yang digunakan untuk menilai status gizi. Pengukuran antropometri dilakukan dengan berbagai cara, meliputi pengukuran Berat Badan (BB), Tinggi Badan (TB), Lingkar Lengan Atas (LiLA), Lingkar Kepala, Lingkar Perut, Rasio Lingkar Pinggang Pinggul (RLPP) [4]

\subsection{Konsep Dasar Kesehatan Lansia}

Menurut World Health Organisation (WHO), lansia adalah seseorang yang telah memasuki usia 60 tahun keatas. Lansia merupakan kelompok umur pada manusia yang telah memasuki tahapan akhir dari fase kehidupannya. Kelompok yang dikategorikan lansia ini akan terjadi suatu proses yang disebut Aging Process atau proses penuaan.

Seiring meningkatnya usia sehingga terjadi perubahan dalam struktur dan fungsi sel, jaringan, serta sistem organ. Perubahan tersebut pada umumnya mengaruh pada kemunduran kesehatan fisik dan psikis yang pada akhirnya akan berpengaruh pada ekonomi dan sosial lansia. Sehingga secara umum akan berpengaruh pada activity of daily living [5]

\subsection{Posyandu Suka Mulya}

Posyandu Suka Mulya adalah salah satu fasilitas kesehatan yang dikelola dari, oleh, untuk, dan bersama masyarakat beroperasi sejak tahun 2003. Posyandu Suka Mulya beralamatkan di Baperkam Desa Kepongpongan Jalan Jembatan Sutera RW.04 Kecamatan Talun Kabupaten Cirebon. Dikelola oleh kader yang beranggotakan 8 orang. Posyandu Suka Mulya melayani pemeriksaan kesehatan masyarakat yang bertempat tinggal di RW 04 dari RT 01 sampai dengan RT 04. Beroperasi sebulan sekali diadakan setiap hari Jumat di mulai pada pukul 08.00 WIB sampai dengan pukul 11.00 WIB.

\subsubsection{Struktur Organisasi}

Berdasarkan Peraturan Menteri Dalam Negeri Nomor 18 Tahun 2018 tentang Lembaga Kemasyarakatan Desa dan Lembaga Adat Desa. Dan secara khusus juga diatur dalam Surat Edaran (SE) Mendagri Nomor 411.3/1116/SJ/ Tahun 2001 perihal Pedoman Umum Revitalisasi Posyandu. Berikut Struktur Organisai Posyandu pada gambar 1.

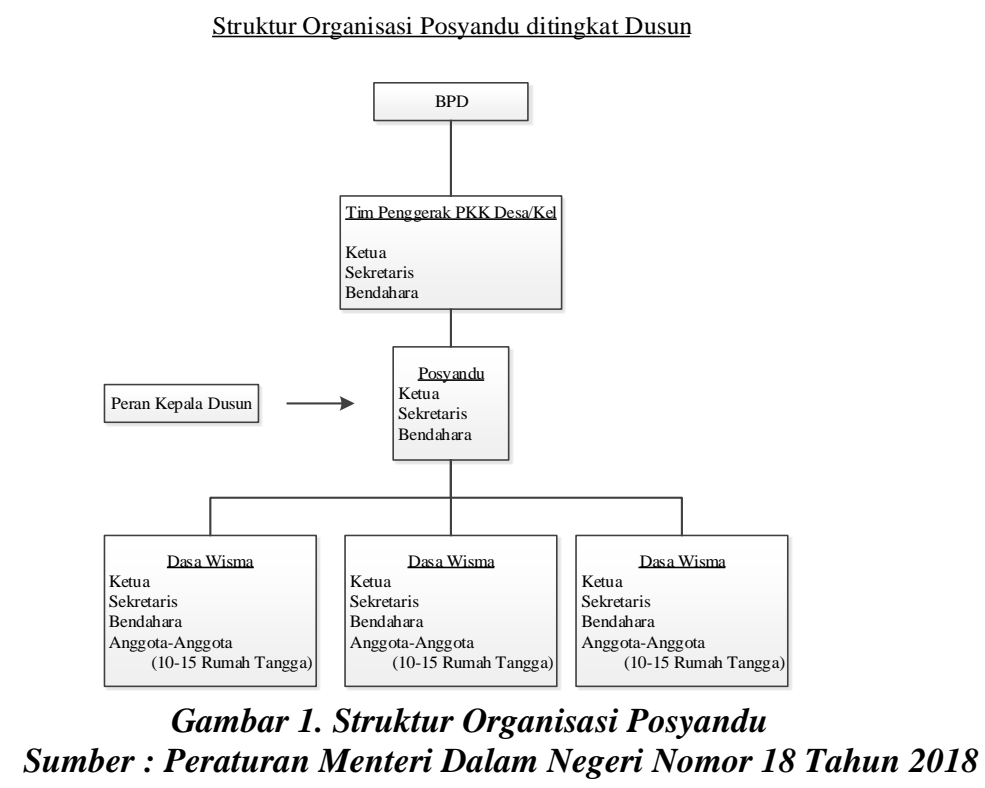

JURNAL DIGIT Vol. 11, No.1 Mei 2021, pp.39 50 


\section{METODE PENELITIAN}

3.1 Use Case Diagram

a. Kader

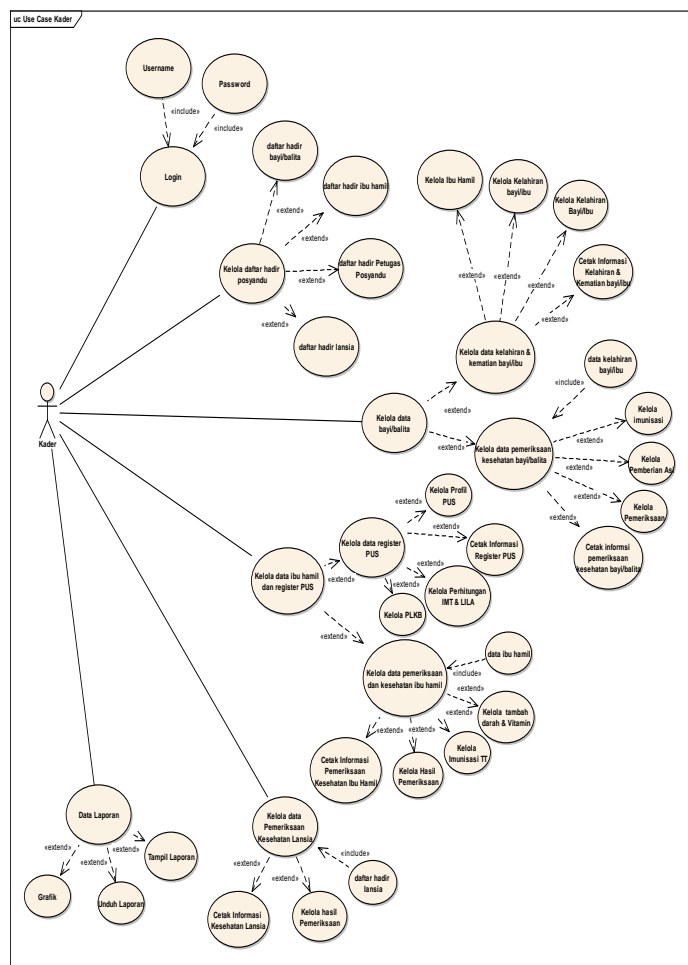

Gambar 2. Use Case Diagram kader

b. Kepala Puskesmas

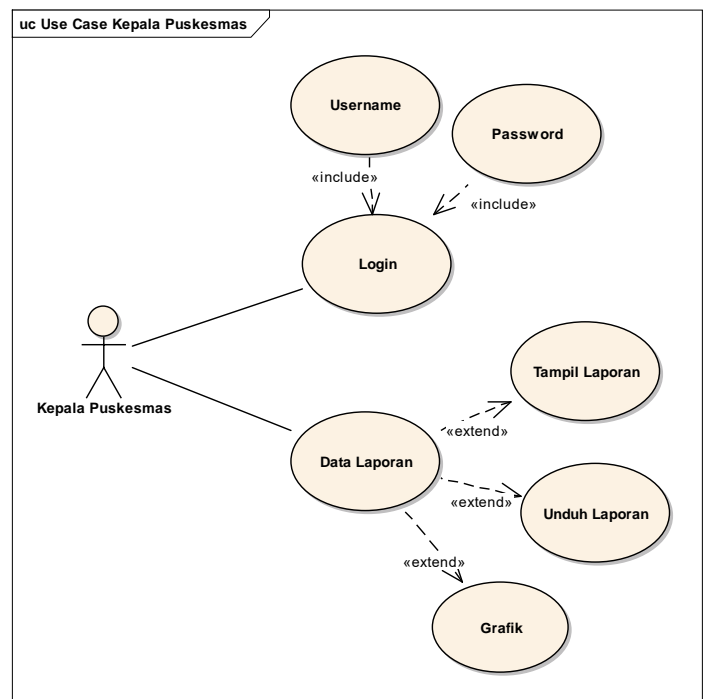

Gambar 3. Use Case Diagram Kepala Puskesmas

Sistem Informasi Posyandu Pendataan Kesehatan Balita, Ibu Hamil, dan Lansia Pada Posyandu Suka Mulya Desa Kepongpongan - (Sri Risma Wati, Lena Magdalena, Muhammad Hatta, Reza Ilyasa) 


\subsection{Activity Diagram}

a. Bagian Kader

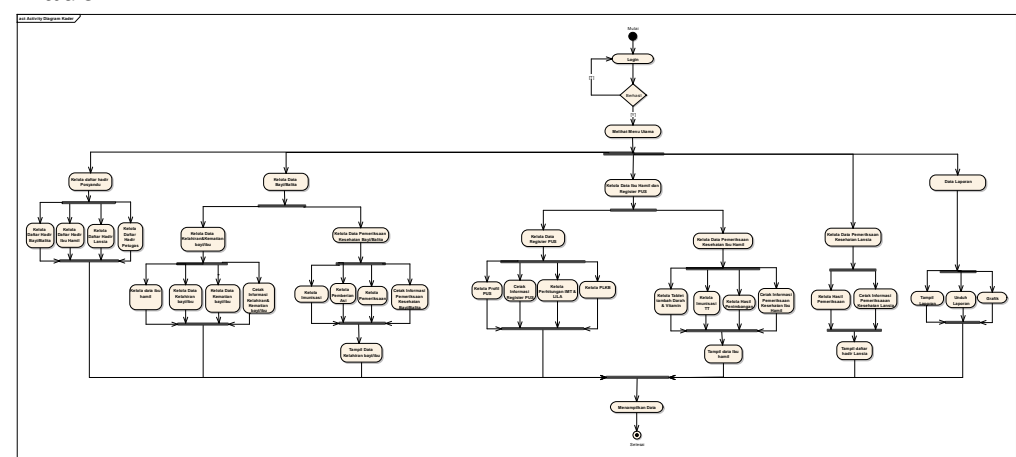

Gambar 4. Activity Diagram kader

b. Kepala Puskesmas

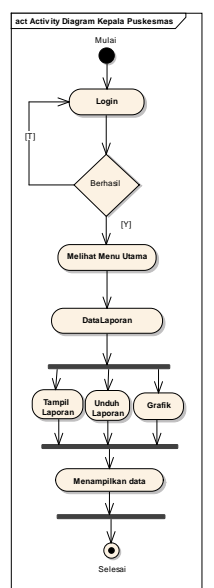

Gambar 5. Activity Diagram Kepala Puskesmas

\subsection{Sequence Diagram}

a. Kader

1) Kelola daftar hadir posyandu

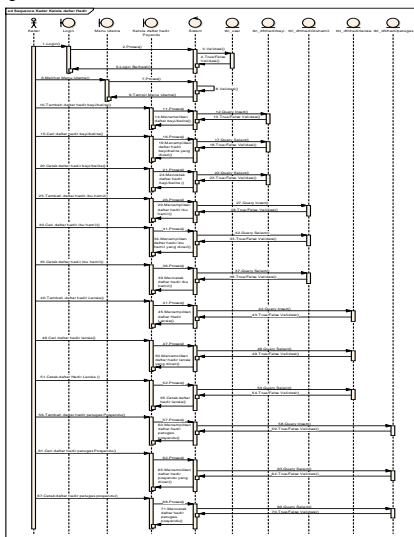

Gambar 6. Sequence Diagram Kelola daftar hadir posyandu 


\section{2) Kelola Data Bayi/Balita}

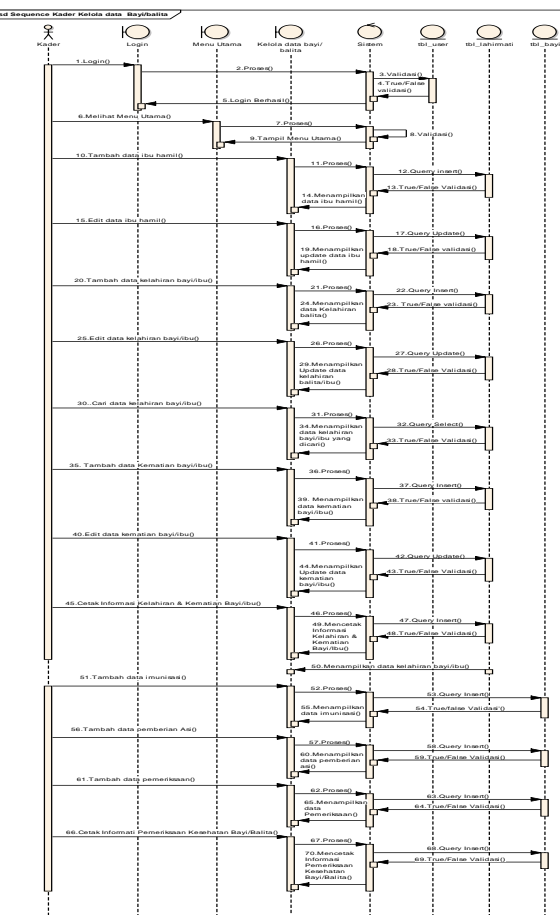

Gambar 7. Sequence Diagram Kelola Data Bayi/Balita

3) Kelola Data Ibu Hamil dan Register PUS

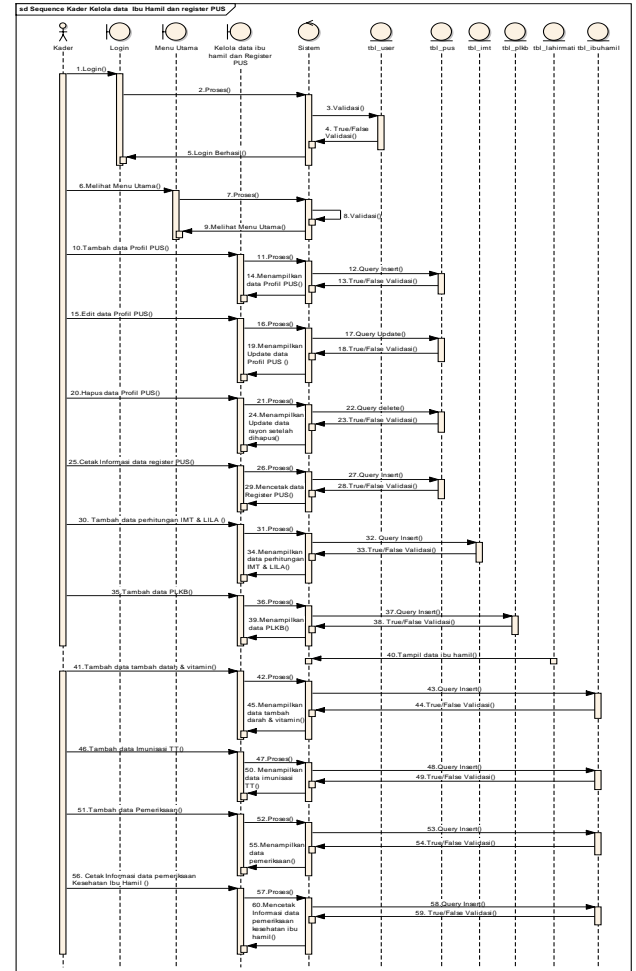

Gambar 8. Sequence Diagram Kelola Data Ibu Hamil dan Register PUS

Sistem Informasi Posyandu Pendataan Kesehatan Balita, Ibu Hamil, dan Lansia Pada Posyandu Suka Mulya Desa Kepongpongan - (Sri Risma Wati, Lena Magdalena, Muhammad Hatta, Reza Ilyasa) 
4) Kelola Data Lansia

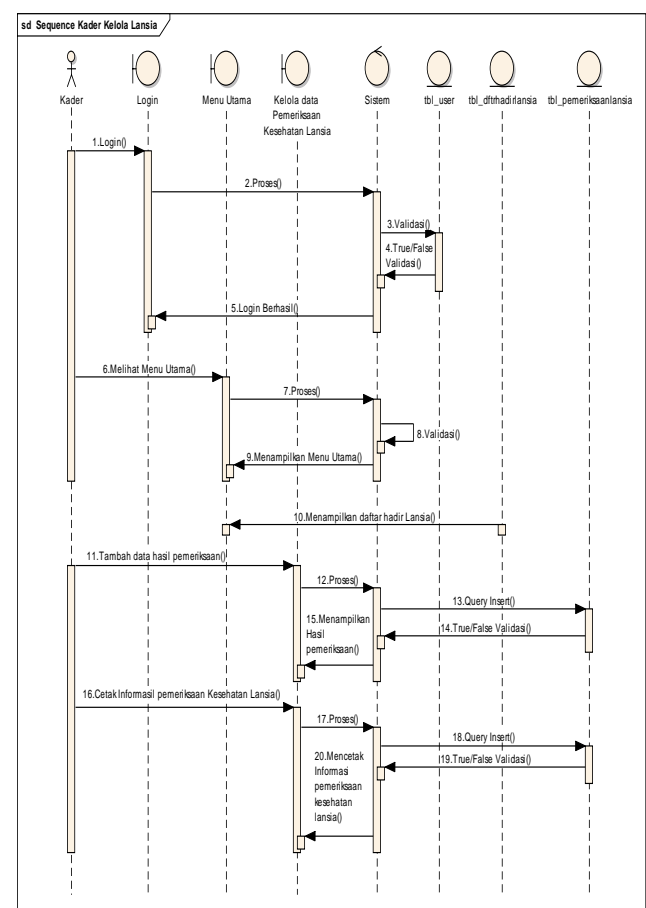

Gambar 9. Sequence Diagram Kelola Data Lansia

5) Kelola Data Laporan

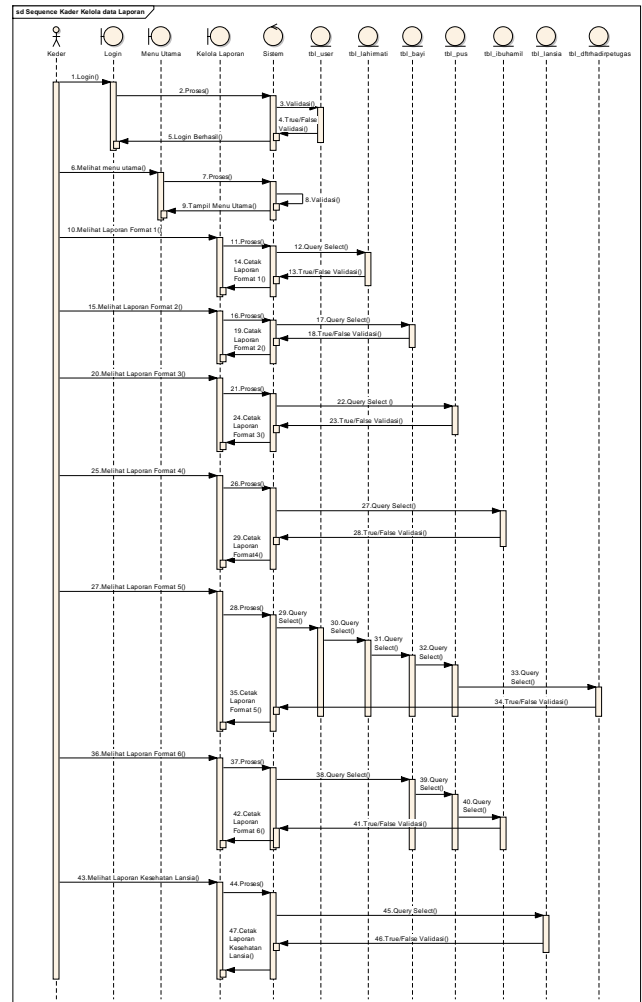

Gambar 10. Sequence Diagram Kelola Data Laporan 


\section{b. Kepala Puskesmas}

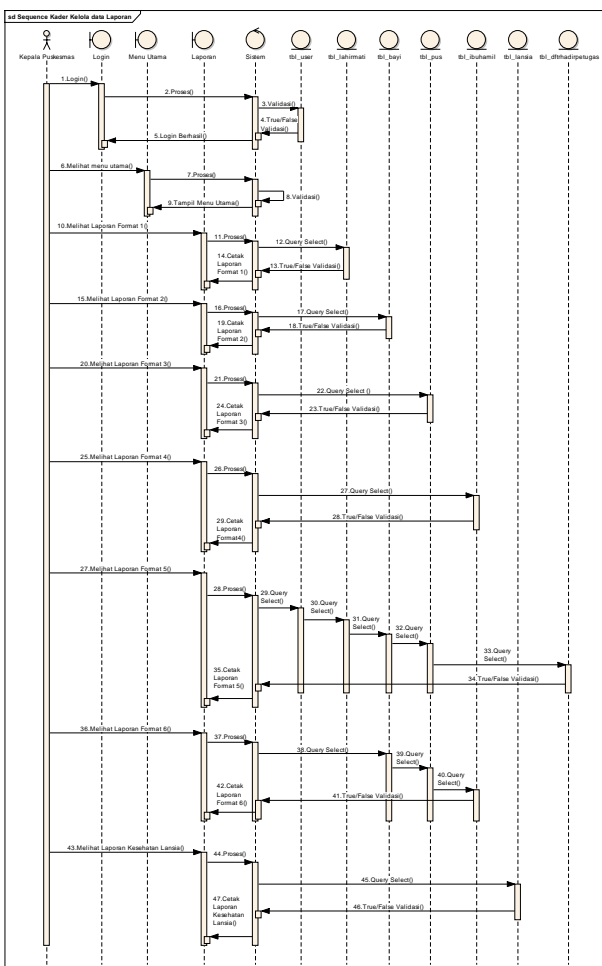

Gambar 11. Sequence Diagram Kepala Puskesmas

\subsection{Class Diagram}

a. Kader

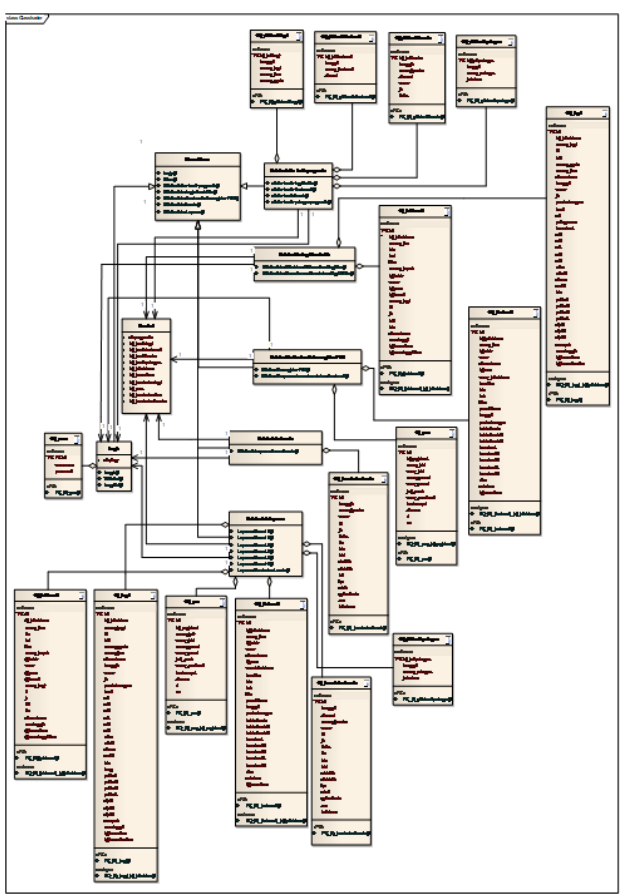

Gambar 12. Class Diagram kader

Sistem Informasi Posyandu Pendataan Kesehatan Balita, Ibu Hamil, dan Lansia Pada Posyandu Suka Mulya Desa Kepongpongan - (Sri Risma Wati, Lena Magdalena, Muhammad Hatta, Reza Ilyasa) 
b. Kepala Puskesmas

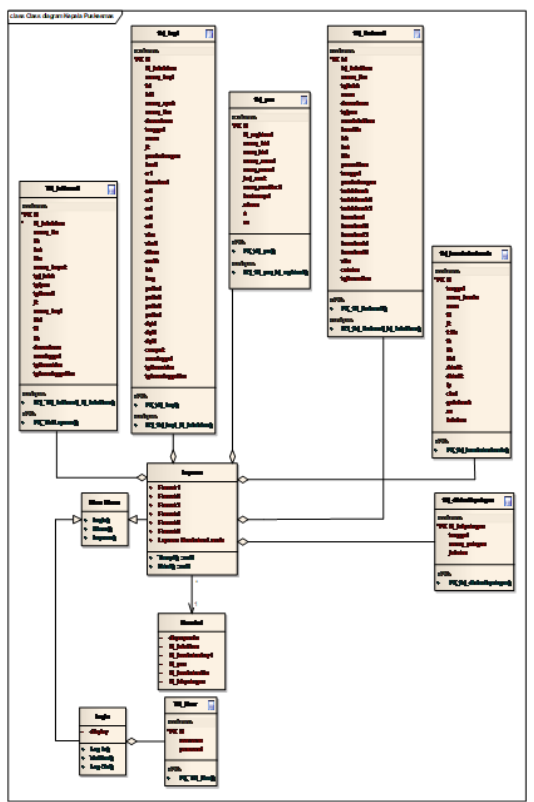

Gambar 13. Class Diagram Kepala Puskesmas

4. PEMBAHASAN

4.1 Tampilan Halaman Web

a. Halaman Login User

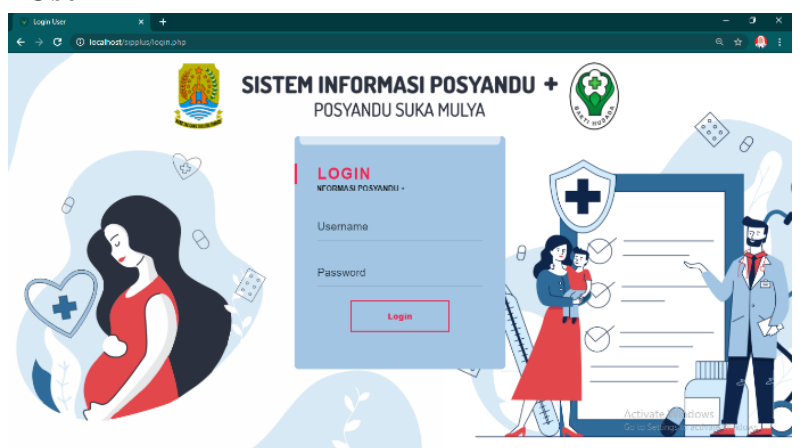

Gambar 14. Halaman Login User

b. Halaman Menu Utama Kader

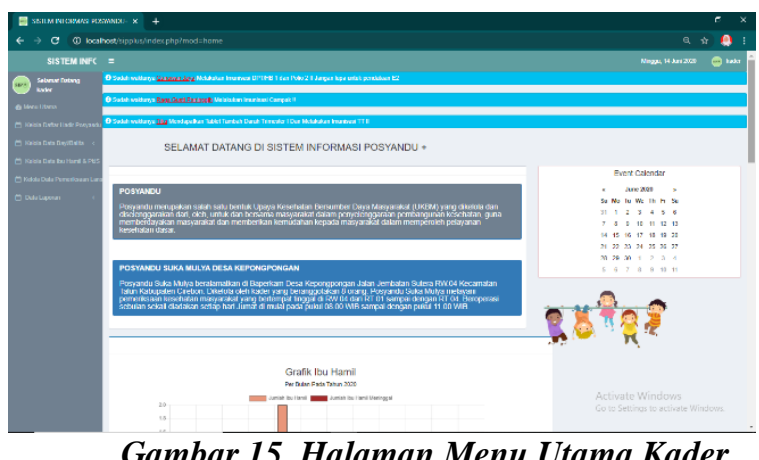

Gambar 15. Halaman Menu Utama Kader 
c. Halaman Menu Utama Kepala Puskesmas

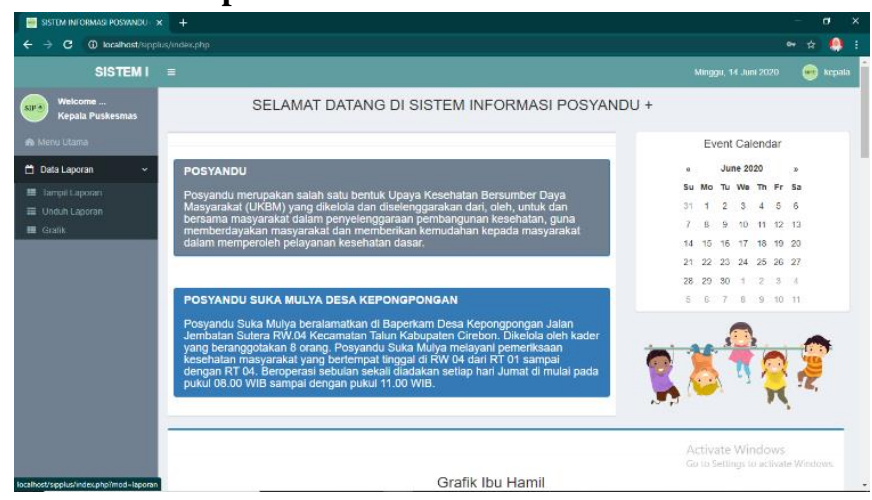

Gambar 16. Halaman Menu Utama Kepala Puskesmas

\subsection{Halaman Output}

a. Data Laporan Format 1

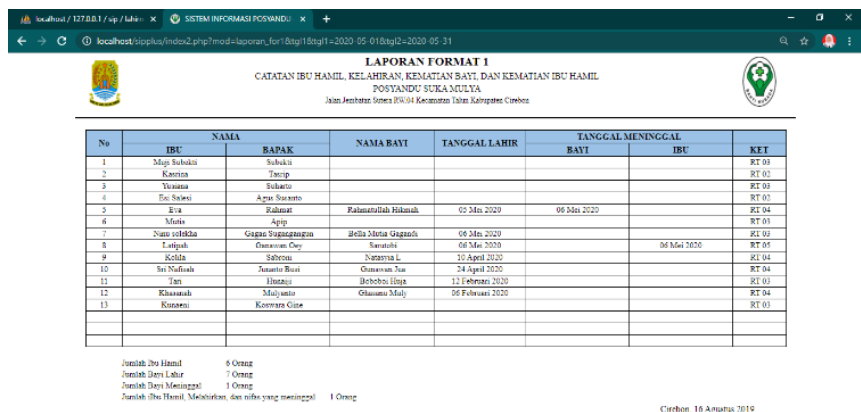

Gambar 17. Halaman Data Laporan Format 1

b. Data Laporan Format 2

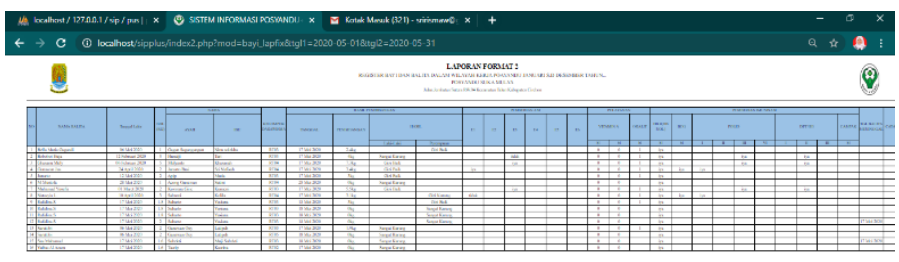

Gambar 18. Halaman Data Laporan Format 2

Sistem Informasi Posyandu Pendataan Kesehatan Balita, Ibu Hamil, dan Lansia Pada Posyandu Suka Mulya Desa Kepongpongan - (Sri Risma Wati, Lena Magdalena, Muhammad Hatta, Reza Ilyasa) 
c. Data Laporan Format 3

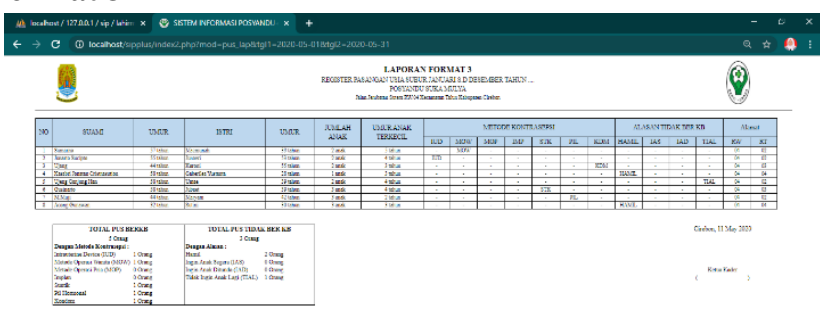

d. Data Laporan Format 4

Gambar 19. Halaman Data Laporan Format 3

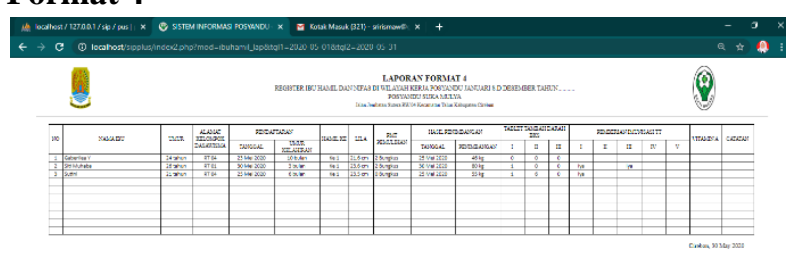

Gambar 20. Halaman Data Laporan Format 4

e. Data Laporan Format 5

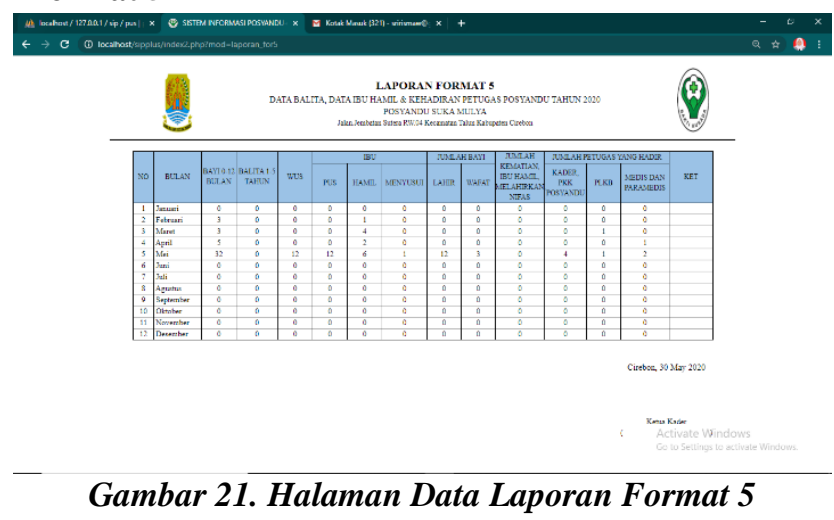

f. Data Laporan Format 6

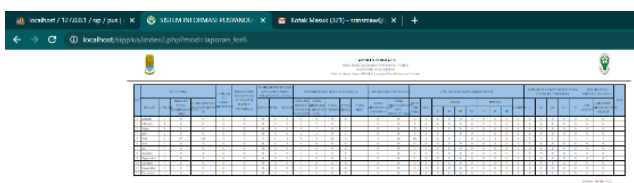

Gambar 22. Halaman Data Laporan Format 6 


\section{g. Grafik Informasi Register PUS}

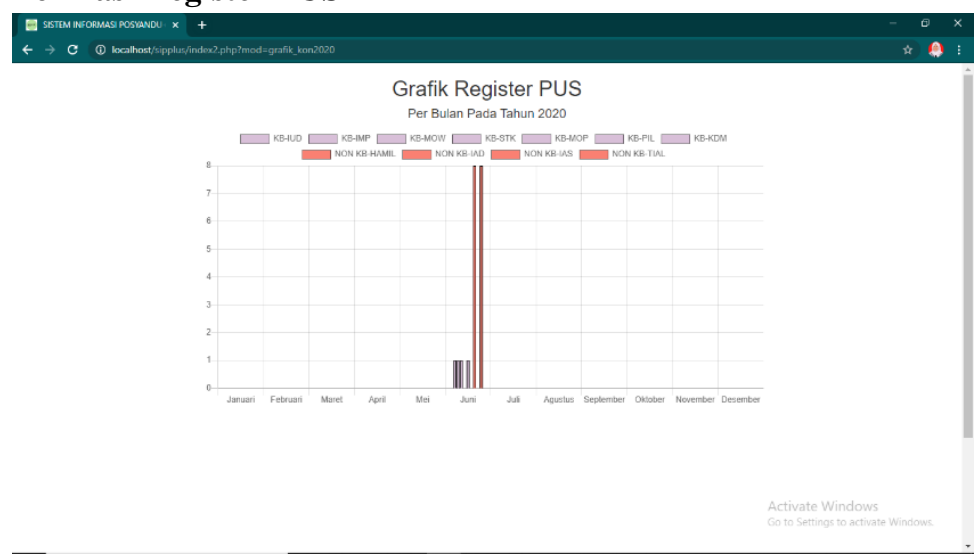

Gambar 18. Grafik Laporan Format 3

\section{KESIMPULAN}

Setelah tahap-tahap dari analisa dan perancangan sistem, kemudian implementasi dan pengujian sistem, penulis memperoleh beberapa kesimpulan, yaitu :

1. Dengan adanya Sipplus dapat Mengatasi kesalahan yang sering terjadi dalam pencatatan form laporan, menghasilkan output laporan berdasarkan format dari dinas kesahatan.

2. Sipplus dapat membantu Memudahkan Kepala Puskesmas dalam menerima Laporan dan memantau kegiatan Posyandu.

3. Menghasilkan grafik informasi kesehatan untuk mantauan kesehatan balita, ibu hamil dan lansia agar lebih baik.

\section{DAFTAR PUSTAKA}

[1] Krismiaji. (2015) Sistem Informasi Akuntansi Edisi keempat. Yogyakarta : Sekolah Tinggi Ilmu Manajemen YKPN

[2] Kementerian Kesehatan RI, Kementerian Kesehatan RI, Sekretariat Jenderal. (2011) Pedoman Umum Pengelolaan Posyandu. Jakarta : Kementerian Kesehatan RI

[3] Sutomo, B dan Anggraini, DY. Menu Sehat Alami Untuk Balita \& Batita, Jakarta : PT. Agromedia Pustaka

[4] Kesehatan Indonesia. Jakarta: Kementrian Kesehatan. Republik ... Kesehatan Republik Indonesia, 2012

[5] Fatmah. Gizi Usia Lanjut. Jakarta:Erlangga. 2010

Sistem Informasi Posyandu Pendataan Kesehatan Balita, Ibu Hamil, dan Lansia Pada Posyandu Suka Mulya Desa Kepongpongan - (Sri Risma Wati, Lena Magdalena, Muhammad Hatta, Reza Ilyasa) 